\title{
New Writing
}

The International Journal for the Practice and Theory of Creative

Writing

\section{From translation to originals ... is it just a short step?}

\section{Şirin Okyayuz}

To cite this article: Șirin Okyayuz (2017) From translation to originals ... is it just a short step?, New Writing, 14:3, 348-368, DOI: 10.1080/14790726.2017.1301961

To link to this article: https://doi.org/10.1080/14790726.2017.1301961

\section{冓 Published online: 28 Mar 2017.}

Submit your article to this journal

LII Article views: 152

View Crossmark data $₫$ 


\title{
From translation to originals ... is it just a short step?
}

\author{
Şirin Okyayuz \\ Department of Translation and Interpreting, Bilkent University, Ankara, Turkey
}

\begin{abstract}
Even today, many examples of contemporary books for children in Turkey are translations. On the other hand, Turkish authors have been writing books for children for some time now and recently different genres of books have also appeared on the Turkish market. One of these genres is biographies about famous people for primary school students. The scope of this study entails translated biographies about famous people for child readers and current Turkish originals in this genre available today. The central questions are: Are the Turkish versions written in this genre imitations of the translations into Turkish, or are there differences between the translations and originals? What was, in a sense, created through the translation of a genre into a local repertoire? The findings of the study reveal how translations affected the formulation and creation of the genre in Turkish, but also reveal that local literary norms were effective in the appropriation of the genre.
\end{abstract}

\section{ARTICLE HISTORY}

Received 10 July 2016

Revised 17 January 2017

Accepted 27 February 2017

\section{KEYWORDS}

Translation of children's literature; biographies for children; appropriation of genres; books for primary school students

\section{Translated children's books and originals side by side}

There is a substantial body of research by Turkish translation scholars on how translators, editors and publishers have continually brought in new ideas from the West, initiating or fostering shifts of paradigm in Turkey (Susam-Saraeva 2010, 231). This transformation involving 'the cultural translation of an Eastern empire following Western models', entailed not only the translations of texts, but also of models and structures (Daldeniz 2010, 129).

Thus, following the establishment of the Republic of Turkey in 1923, the role of translation was central. The traditionally low status of translation was reversed in Turkey's case as it was the essential source of knowledge and culture (Kurultay 1999, 13). This is especially true of modern Turkish literature where the Turkish brand of modernism embraced after the establishment of the Republic of Turkey to the present day was founded 'not by deconstructing originals but by imitating them', (YazıcI 2010, 60). Several prominent translation scholars in Turkey have traced the evolution of literature and writing in Turkish through the contributions of translation stating that translations from 'developed' countries in which a certain genre of literature is richer served to transfer a literary genre (Yazıcı 2007, 246). In Paker's $(2004,6)$ words, Turkey is 'a nation divided or suspended between East and West'. Initially translations served as the tool for the entre of a new literary genre and, while translations continue to be undertaken in order for Turkey

CONTACT Şirin Okyayuz yener@bilkent.edu.tr 
to keep up with the publications in the West and style, it's accumulation in the ways of the Western originals also start to be written by writers who imitate the genre in Turkish. Historically, and even in contemporary times, this has always been the case in Turkey with, for example, the state-run Translation Bureau being set up in the 1940s under the Ministry of Education with the intention of laying the foundations of a 'Turkish Renaissance', which the Bureau believed would occur through the task of translating the European Classics and Ancient Greek and Latin works taking into account their share in laying the foundations of Western civilisation (Yücel 1946, 1). To this day translations from the West still enjoy popularity in a variety of genres, and even with the rise of Islamic oriented publishing houses translations from Western sources are an indispensable part of the publication lists of Islamic publishing houses (Daldeniz 2010, 129). This is also true for children's literature in Turkey as there were still relatively few examples originally produced in Turkish.

Even today, literature and translation scholars alike lament the fact that very few authors produced works specifically for children in Turkish (Tuğcu 2004, 227). Literary experts refer to a limited number of examples where adult themes and stories were written in a way as to appeal to children, with the highest selling authors concentrating on melodramatic themes, stories about life in rural Turkey and science fiction (Ateş 1998, 256, 258).

Though authors cite examples of translations for children into Turkish as far back as 1869, continuing with new magazines in 1882 and 1897 (Neydim 2000, 30), they also underline the fact that a systematic translation of 'the world classics' for children, in an effort to catch up with the West in terms of modern norms, started in the 1950s (Neydim 2000, 33).

The first picture book for children was published in 1964 and most of the books written until the 1940s were written for 'adult-like children' (Çelik 2014, 203-204). Researchers compiling bibliographies show that efforts to translate children's literature slowed down in the 1970s, with Turkish authors being motivated to write for children, and underline that even then examples were few (Neydim 2000, 39). Educational reference books from children were even fewer with, for example, efforts by historians like M. İ. Çığ who wrote in the 1990s to inform children about Sumerian culture (Öztürk 2002, 182). The first examples of the science fiction genre were translated for children in 1954 and were the first examples which were not used for 'disciplining children in a certain manner' or which had 'high literary value' (Özdeş 1999, 537-540). In short, in addition to a lack of original children's books, there was also a lack of examples from different genres of books for children.

It is clear that most of the examples of contemporary books for children in Turkey, even today, are translations. But Turkish authors have been writing books for children for some time now and, recently, different genres of books are also being written as authors and publishing houses are aware that there is a clientele (i.e. parents and children) for these types of books.

Through personal experience as a translator, editor and translation portfolio compiler of children's books published by a variety of publishing houses, though there is no set or norms governing the choice of translations into Turkish, it may be stated that there are certain criteria through which publishing houses choose the books and genres they would like to translate. The first of these is statistical and financial data as to the sales of 
certain genres. For example, if the sales of a picture book about famous painters chosen by the publishing house (to try out a new genre on Turkish readers) are high, it is only logical that the publishing house will want to continue to publish in this genre; or, for example, worldwide bestsellers sell in Turkey too. Secondly, smaller publishing houses follow major trends set by major publishing houses. For example, if one of the most prominent publishing houses for children's literature (i.e. Doğan Egmont) translates a certain genre or author due to the financial and infrastructural ability of said publishing house in distributing, advertising and promoting the translations in question, others will follow its footsteps with other examples of the genre or author in the belief that a market has been established for that 'product'. A third concern governing the publication choices of publishing houses is of course originality of the source text. For example, a new (untranslated) author or a new genre will stand out as an original among other publications. A fourth concern governing the choice of publishing houses is financial, in regards to how much they will have to pay for the copyright, how much they will pay for printing, translation etc., and whether they have the budget for such an initiative or if they need to look for works by authors who will demand lower copyright fees. A fifth consideration is that, due to the tendency to translate from major European languages (i.e. English, French, German, etc.) and the fact that it would be difficult to find translators with experience in a certain genre in other languages, (which are rarely taught in university translation and interpreting departments), publishing houses tend to choose from examples of European and American literature and preferably in certain languages. Though there are a variety of other factors governing choices, these five are generally the major deciding factors. As stated at the beginning of the research, once translated examples are brought to Turkish readers, a reading habitus is formed and a clientele is present, this is followed by the creation of originals in the genre. One of the examples for this evolution in genres is biographies about famous people for primary school students.

In a bibliography of children's literature available in Turkey (both translations and originals from the establishment of the Republic until 1979) there is only a single biography written in Turkish. It is about famous Turkish poets and writers and aimed at middle school children (Şenalp and Şan 1981, 21). There is not a single publication for primary school students. Furthermore, the majority of the books listed are translations (Şenalp and Şan 1981). Ten years later, in another bibliography, there is not a single example of a reference book for children at any level and the dominance of translations continues (Şirin 1989, 390-400). But, after 2010, examples of biographies for primary school children started to be published in Turkish, and today there are numerous examples of this genre.

\section{A genre incorporated through translations}

At least 50\% of the children's books published in Europe are translated and Europeans consider it important to have books from many countries available for children to read (Cotton 2000, 68). Just as it is important to acquaint the child with cultures besides their own, it is equally important to have a repertoire of local books which in turn inform the child about the society that they are a part of. Thus, translations and originals are both important, especially when it comes to children.

In line with this thought, the scope of this study entails translated children's books, biographies about famous people and current Turkish originals in this genre available today. 
The central questions are: What types of works were written in Turkish? Are the Turkish versions of biographies for children imitations of the translations into Turkish, or are there differences between the translations and originals? When the authors produced Turkish versions, from which repertoire other than that of the translations of the genre did they draw from? In short, what was, in a sense, created through the translation of a genre into a local repertoire?

At this point it is beneficial to consider the use of translations and how they link into the creations of new genres within a literary system. As I. Even-Zohar states:

[...] I conceive of translated literature not only as an integral system within any literary polysystem, but as a most active system within it [...] Through the foreign works, features (both principles and elements) are introduced into the home literature which did not exist there before. These include possibly not only new models of reality to replace the old and established ones that are no longer effective, but a whole range of other features as well, such as a new (poetic) language, or compositional patterns and techniques. (1990, 46-47)

In referring to 'young', 'peripheral' or 'weak' literary systems and literary vacuums, translation serves as the basis of import and the next step leads to the creation of originals (Even-Zohar 1990, 47).

In this regard $\mathrm{G}$. Toury refers to the idea of introducing translations into a culture 'to cater for their needs' $(2002,155)$.

[...] in more complex cases, not only individual texts may be introduced into a culture but hitherto non-existing models too - i.e., preorganized options which can be used as instructions for future productions. This is the case be they text-types, or models for the representations of reality [...] This reflects, of course a much more radical, repertoremic sense of placing new options at the disposal of a culture, which is normally brought about by groups of texts rather than single instances of linguistic performance [...]. (Toury 2002, 154)

In fact, communicative interaction between functionally differentiated systems, turns a system into an auto-poetic (self-creating) one (Yazıcı 2010, 59).

In line with these views, the corpus of the study entails translations and Turkish originals of reference books about famous people for 6-10 year olds, in other words for primary school children.

Turkish children attend primary school between ages 6 through 10. It may be argued that, in primary school children may require resources befitting their cognitive levels. After primary school, it may be argued that they would probably use the Internet more frequently and can also consult other resources.

The books analysed within the scope of this study were compiled according to certain criteria. Initially the largest and most popular bookstores in Ankara, ${ }^{1}$ the capital of Turkey, were located. The persons in charge of the children's sections were interviewed, providing information about the books that were available. Only books that are currently available in the 6-10 years range ${ }^{2}$ and among these only those books that were specifically about famous people were included in the study. ${ }^{3}$

Looking through sales records, those translations and originals that were available in the four top ranking bookstores were included in the study. Thus, the corpus reflects what type of books about famous Turkish and foreign people are available and being read by 6 to 10 -year-old age range presently. 
Looking through the backdated inventories in the stores and confirming the findings with the people in charge of the sections, it may be stated that Turkish versions of biographies of famous people for the 6-10 age group are a relatively new genre in Turkey. Most of the examples were published in 2013-2015 with a few examples dating back to 2010 .

The study does not entail the comparative analysis of translations and originals, but a thematic study of the contents of originals and translations. The focus is: What features of the genre were borrowed from the translations to create the original versions, and the differences between the discourses and content of the translated books and originals. The findings reveal how translations affected the formulation and creation of the genre in Turkish, but also reveal that primarily local literary norms were also effective in the appropriation of the genre.

\section{Children's books series studied ${ }^{4}$}

The following section entails a short description of the translations and originals studied.

Table 1. Eğlenceli Tarih (Fun History) Series - TiMAŞ Yayınları Publishing House (primary school years) ${ }^{5}$

\begin{tabular}{llrr}
\hline Book & Subject & Author & Year \\
\hline $\begin{array}{l}\text { Gizli Kurucu Ertuğrul Gazi } \\
\text { (Ertuğrul Gazi the Secret Founder) }\end{array}$ & $\begin{array}{c}\text { The life of Ertuğrul Gazi, one of the forefathers of the } \\
\text { Ottoman dynasty. }\end{array}$ & Metin Özdamarlar & 2015 \\
$\begin{array}{c}\text { Osmanlı Süper Beyinleri } \\
\text { (Ottoman Super Brains) }\end{array}$ & $\begin{array}{l}\text { The lives of 6 scientists who lived in Ottoman times } \\
\text { and contributed with inventions and theories to } \\
\text { fields like astronomy and mathematics. }\end{array}$ & Mazlum Akın & 2015 \\
& & \\
\hline
\end{tabular}

In contemporary Western children's literature there is a change of attitude, a movement from concentrating on message versus effect towards a 'wider more literary apprehension of the style in children's literature' (Teigland 1999, 1-2). Thus, a children's book is no longer reserved for pedagogy. In line with this, the creators of the series (see Table 1) seem to have prioritised the child's enjoyment of the book while imparting historical facts and information. This can be noted in the use of jokes and caricatures, an example of which can be provided from a joke within a caricature used in the section detailing the migration of the Turks from Central Asia. The caricature depicts two Central Asian Turks from the time period with appropriate headgear and outfits. One is holding a smart tablet (similar to an iPad) depicting the picture of a road. This is an anachronism. The speech bubbles can be translated as follows: Man left: How do you find your way?, Man right: There is a gadget called navigation, stupid. Several examples such as the one given have been provided with a view to enhancing the child's enjoyment.

Table 2. Ünlüler Bir Gün $1 \& 2$ - TiMAŞ ÇOCUK Yayınları (A Day with Famous People - TiMAŞ Children's Publications) $(+7 \text { years })^{6}$

\begin{tabular}{|c|c|c|c|}
\hline Book & Subject & Author & Year \\
\hline $\begin{array}{l}\text { Evliya Çelebi ile Bir Gün } \\
\text { (A Day with Evliya Çelebi) }\end{array}$ & $\begin{array}{l}\text { Evliya Çelebi, an Ottoman who travelled through the Ottoman } \\
\text { Empire and neighbouring lands over a period of } 40 \text { years, recording } \\
\text { his commentary in a travelogue. }\end{array}$ & $\begin{array}{r}\text { Mustafa } \\
\text { Orakçı }\end{array}$ & 2014 \\
\hline $\begin{array}{l}\text { Barbaros'la Bir Gün } \\
\text { (A Day with Barbaros) }\end{array}$ & $\begin{array}{l}\text { Hayreddin Barbarossa, an Ottoman admiral, whose naval victories } \\
\text { secured Ottoman dominance over the Mediterranean during the } \\
\text { mid-sixteenth century. }\end{array}$ & $\begin{array}{r}\text { Mustafa } \\
\text { Orakçı }\end{array}$ & 2014 \\
\hline
\end{tabular}


Table 2. Continued.

\begin{tabular}{|c|c|c|c|}
\hline Book & Subject & Author & Year \\
\hline $\begin{array}{l}\text { Piri Reis'le Bir Gün } \\
\text { (A Day with Piri Reis) }\end{array}$ & $\begin{array}{l}\text { Piri Reis, an Ottoman admiral, geographer, and cartographer, known } \\
\text { for his maps and charts describing the important ports and cities of } \\
\text { the Mediterranean Sea. }\end{array}$ & $\begin{array}{r}\text { Mustafa } \\
\text { Orakçı }\end{array}$ & 2014 \\
\hline $\begin{array}{l}\text { Hezarfen'le Bir Gün } \\
\text { (A Day with Hezarfen) }\end{array}$ & Hezarfen, a famous Ottoman aviator. & $\begin{array}{r}\text { Mustafa } \\
\text { Orakçı }\end{array}$ & 2013 \\
\hline $\begin{array}{l}\text { Fatih'le Bir Gün } \\
\text { (A Day with Fatih) }\end{array}$ & $\begin{array}{l}\text { Mehmed the Conqueror, an Ottoman sultan who conquered } \\
\text { Constantinople (modern-day Istanbul) and brought an end to the } \\
\text { Byzantine Empire. }\end{array}$ & $\begin{array}{r}\text { Mustafa } \\
\text { Orakçı }\end{array}$ & 2014 \\
\hline $\begin{array}{l}\text { Mevlana'yla Bir Gün } \\
\text { (A Day with Mevlana) }\end{array}$ & $\begin{array}{l}\text { Rumi, a thirteenth century Persian poet, jurist, Islamic scholar, } \\
\text { theologian, and Sufi mystic. }\end{array}$ & $\begin{array}{r}\text { Mustafa } \\
\text { Orakçı }\end{array}$ & 2014 \\
\hline $\begin{array}{l}\text { Hacı Bektaş Veli'yle Bir Gün } \\
\text { (A Day with Hadjı Bektash } \\
\text { Veli) }\end{array}$ & $\begin{array}{l}\text { Hadji Bektash Veli, an Alevi Muslim mystic, humanist and philosopher } \\
\text { from Anatolia, who is revered for an Islamic understanding that is } \\
\text { esoteric (spiritual), rational, progressive and humanistic. }\end{array}$ & $\begin{array}{r}\text { Mustafa } \\
\text { Orakçı }\end{array}$ & 2015 \\
\hline $\begin{array}{l}\text { Koca Yusuf'la Bir Gün } \\
\text { (A Day with Yusuf Ismail) }\end{array}$ & $\begin{array}{l}\text { Yusuf Ismail, a Turkish professional wrestler who competed in Europe } \\
\text { and the US as Yusuf Ismail the Terrible Turk during the 1890s. }\end{array}$ & $\begin{array}{r}\text { Mustafa } \\
\text { Orakçı }\end{array}$ & 2015 \\
\hline $\begin{array}{l}\text { Halide Edip'le Bir Gün } \\
\text { (A Day with Halide Edib) }\end{array}$ & $\begin{array}{l}\text { Halide Edib Adıvar a Turkish novelist, nationalist and political leader } \\
\text { for women's rights. }\end{array}$ & $\begin{array}{r}\text { Mustafa } \\
\text { Orakçı }\end{array}$ & 2015 \\
\hline $\begin{array}{l}\text { Ertuğrul Gazi'yle Bir Gün } \\
\text { (A Day with Ertuğrul) }\end{array}$ & $\begin{array}{l}\text { Ertuğrul Ghazi, the father of Osman I, the founder of the Ottoman } \\
\text { Empire and the leader of the Kayı clan of the Oghuz Turks. }\end{array}$ & $\begin{array}{r}\text { Mustafa } \\
\text { Orakçı }\end{array}$ & 2015 \\
\hline $\begin{array}{l}\text { Biruni'yle Bir Gün } \\
\text { (A Day with Al-Biruni) }\end{array}$ & $\begin{array}{l}\text { Al-Biruni, one of the scholars of the medieval Islamic era, well versed } \\
\text { in physics, mathematics, astronomy, and natural sciences, and also } \\
\text { a distinguished historian, chronologist and linguist. }\end{array}$ & $\begin{array}{r}\text { Mustafa } \\
\text { Orakçı }\end{array}$ & 2015 \\
\hline $\begin{array}{l}\text { Nasreddin Hoca'yla Bir Gün } \\
\text { (A Day with Nasreddin) }\end{array}$ & $\begin{array}{l}\text { Nasreddin, a Seljuk satirical Sufi, considered a populist philosopher } \\
\text { and wise man, remembered for his funny stories and anecdotes. }\end{array}$ & $\begin{array}{r}\text { Mustafa } \\
\text { Orakçı }\end{array}$ & 2015 \\
\hline $\begin{array}{l}\text { Osman Gazi'yle Bir Gün } \\
\text { (A Day with Osman I) }\end{array}$ & $\begin{array}{l}\text { Osman Ghazi ben Ertugrul the leader of the Ottoman Turks and the } \\
\text { founder of the dynasty that ruled the Ottoman Empire. }\end{array}$ & $\begin{array}{r}\text { Mustafa } \\
\text { Orakçı }\end{array}$ & 2015 \\
\hline $\begin{array}{l}\text { Kanuni'yle Bir Gün } \\
\text { (A Day with Suleiman the } \\
\text { Magnificent) }\end{array}$ & $\begin{array}{l}\text { Suleiman I (Suleiman the Magnificent) who was the tenth and } \\
\text { longest-reigning Great Sultan of the Ottoman Empire. }\end{array}$ & $\begin{array}{r}\text { Mustafa } \\
\text { Orakçı }\end{array}$ & 2015 \\
\hline $\begin{array}{l}\text { Nene Hatun'la Bir Gün } \\
\text { (A Day with Nene Hatun) }\end{array}$ & $\begin{array}{l}\text { Nene Hatun, a Turkish folk heroine, who is famous for fighting against } \\
\text { Russian forces in the Russo-Turkish War of } 1877-1878 \text {. }\end{array}$ & $\begin{array}{r}\text { Mustafa } \\
\text { Orakçı }\end{array}$ & 2015 \\
\hline $\begin{array}{l}\text { Itri'yle Bir Gün } \\
\text { (A Day with Itri) }\end{array}$ & $\begin{array}{l}\text { Mustafa Itri, an Ottoman musician, composer, singer and poet. With } \\
\text { over a thousand works to his name, he is regarded as the master of } \\
\text { Turkish classical music. }\end{array}$ & $\begin{array}{r}\text { Mustafa } \\
\text { Orakçı }\end{array}$ & 2015 \\
\hline
\end{tabular}

This series, detailed in Table 2, follows a storytelling technique which is used in children's books in the West. Today, there is an abundance of examples of stories in which invented characters are placed within settings which are historically accurate in terms of time and place and in terms of customs, social mores and available technologies (Cheetham 2013, 159). In the case of the series, the leading child character is transported with a magical key to the time the famous person lived in.

In this series there is an information box on the third page of every book explaining what the child will achieve/gain/learn when reading that specific volume.

In an age where experts state that the developments in the children's book market and the changing notion of the child have inspired movements towards 'less pedagogically oriented and more entertainment oriented texts for children' (Gerber 2008, 142), in Turkey some of the examples of the genre seem to adhere to older norms.

This is not a unique occurrence, as for example in the case of Urdu children's literature. Haider $(1998,108)$ cites examples where 'a great deal of emphasis was laid on the upbringing of children to make them ideal members of the family and society at large', and also recitations on how children should respect their elders, obey their parents, pursue knowledge and also perform their religious obligations.

Similar examples can be provided from the information boxes/bubbles in all of the books in the discussed series. The publishers attest that the child who reads the book 
will understand Turkey in its struggle for national freedom, will understand the sacrifices made by those who saved the nation, will be respectful of adults, will want to learn our traditions and make these live on, will notice the importance of solidarity and unity in the Muslim world and so on and so forth. (Further examples are provided in detail in the section below: 'Difference 2 '.)

Table 3. Kim Kimdir? (Who's Who) Series - Mikado Çocuk Yayınları (7-9 year old) ${ }^{7}$

\begin{tabular}{lllr}
\hline Book & \multicolumn{1}{c}{ Subject } & Author & Year \\
\hline $\begin{array}{l}\text { Dede Korkut Kimdir? } \\
\text { (Who is Dede Korkut?) }\end{array}$ & $\begin{array}{c}\text { The tales and life of Dede Korkut, who talks of } \\
\text { the origins of the Turks. }\end{array}$ & Nevzat Basım & 2015 \\
$\begin{array}{l}\text { Mimar Sinan Kimdir? } \\
\text { (Who is Mimar Sinan) }\end{array}$ & $\begin{array}{c}\text { The life and masterpieces of Architect } \\
\text { Sinan in Ottoman times. }\end{array}$ & Nevzat Basım & 2015 \\
$\begin{array}{l}\text { Edison Kimdir? } \\
\text { (Who is Edison?) }\end{array}$ & The life and inventions of Thomas Edison. & Nevzat Basım & 2015 \\
\hline
\end{tabular}

In depicting modern historical fiction the necessity of accuracy include various epitextual extras, introduction, postscripts, historical notes and research supporting the main text (De Groot 2010, 7-10). In line with this trend seen in the West, the books in this series, presented in Table 3, contain a timeline at the end, chronicling either the events that were referred to in the volume alongside events that occurred in the world at the same time, or the events in the lifetime of the famous figure referred to. The chronological time line of the events of Thomas Edison's life given at the end of the book on Edison, or a list of events occurring in the world and Anatolia during Architect Sinan's lifetime in the volume on the architect in question are examples of timelines from the series. Each volume also contains a bibliography.

Table 4. Elma Çocuk (Apple Children's) Series (+7 and 8-10 years) ${ }^{8}$

\begin{tabular}{lccc}
\hline Book & Subject & Author & Year \\
\hline $\begin{array}{l}\text { Hezarfen Üçmak Özgürlüktür } \\
\text { (Hezarfen Flying is Freedom) }\end{array}$ & $\begin{array}{c}\text { A tale about how Hezarfen, (a famous aviator in } \\
\text { seventeenth century Ottoman Empire) flew and } \\
\text { the way the Sultan condemned him for it. }\end{array}$ & Sait Munzur & 2013 \\
$\begin{array}{l}\text { Virginia Woolf: Görünmeyenin Yazarı } \\
\text { (Virginia Woolf the Writer of the } \\
\text { Invisible) }\end{array}$ & $\begin{array}{c}\text { The story of Virgina Woolf and how she strived } \\
\text { against all odds to write and create. }\end{array}$ & $\begin{array}{c}\text { Luisa Antolin Villota } \\
\text { (Trans: Kemal }\end{array}$ & 2012 \\
& & Atakay) & \\
\hline
\end{tabular}

In the case of this series (see Table 4), it seems that both the authors (Turkish and English) believe that a story used to relay historical facts would entice the child reader. As it is important to have history and the story interact in children's books (Cheetham $2013,157)$, the Turkish original has followed in the tracks of the foreign author of the series, creating such a story for child readers.

Table 5. Tefrika Yayın Evi Çocuk Edebiyatı (Tefrika Publishing Children's Literature) Series (7-9 years) ${ }^{9}$

\begin{tabular}{llcl}
\hline Book & Subject & Author & Year \\
\hline $\begin{array}{c}\text { Küçük Turgut Uyar ve Saati } \\
\text { (Little Turgut Uyar and his Watch) }\end{array}$ & $\begin{array}{c}\text { Turgut Uyar's (a well-known poet writing in the } \\
\text { 'Second New' vein) childhood adventure where } \\
\text { he wants a watch. }\end{array}$ & $\begin{array}{c}\text { Emre Gül \& } \\
\text { Önder Yetişen }\end{array}$ & 2015 \\
$\begin{array}{c}\text { Küçük Behçet Necatigül ve Yıldızı } \\
\text { (Little Behçet Necatigil and His Star) }\end{array}$ & $\begin{array}{c}\text { Behçet Necatigil, a leading Turkish author, poet } \\
\text { and translator, missed his father and named } \\
\text { a star after him when he was a child. }\end{array}$ & $\begin{array}{c}\text { Emre Gül \& } \\
\text { Önder Yetişen }\end{array}$ & 2015 \\
$\begin{array}{c}\text { Küçük Edip Cansever ve Çiçeği } \\
\text { (Little Edip Cansever and His Flower) }\end{array}$ & $\begin{array}{c}\text { Edip Cansever, a Turkish poet, first harmed } \\
\text { then took care of a flower. }\end{array}$ & $\begin{array}{c}\text { Emre Gül \& } \\
\text { Önder Yetişen }\end{array}$ & 2015 \\
\hline
\end{tabular}


Table 5. Continued.

\begin{tabular}{|c|c|c|c|}
\hline Book & Subject & Author & Year \\
\hline $\begin{array}{l}\text { Küçük Tezer Özlü ve Gece-Gündüz } \\
\text { (Little Tezer Özlü and Night \& Day) }\end{array}$ & $\begin{array}{l}\text { Tezer Özlü , Turkish writer of children's stories } \\
\text { learned about the universe and not to boast } \\
\text { about learning. }\end{array}$ & $\begin{array}{l}\text { Emre Gül \& } \\
\text { Önder Yetişen }\end{array}$ & 2015 \\
\hline $\begin{array}{l}\text { Küçük Fazıl Hüsnü Dağlarca ve Köpeği } \\
\text { (Little Fazıl Hüsnü Dağlarca } \\
\text { and His Dog) }\end{array}$ & $\begin{array}{l}\text { Fazıl Hüsnü Dağlarca was one of the most prolific } \\
\text { Turkish poets of republican Turkey, he wanted } \\
\text { a dog as a child. }\end{array}$ & $\begin{array}{l}\text { Emre Gül \& } \\
\text { Önder Yetişen }\end{array}$ & 2015 \\
\hline $\begin{array}{l}\text { Küçük Oktay Rıfat ve Yazdığı Şiir } \\
\text { (Little Oktay Rıfat and the Poem } \\
\text { He Wrote) }\end{array}$ & $\begin{array}{l}\text { Oktay Rifat Horozcu, a Turkish writer and } \\
\text { playwright, and one of the forefront poets of } \\
\text { modern Turkish poetry since the late 1930s and } \\
\text { a poem he wrote for his girlfriend in first grade. }\end{array}$ & $\begin{array}{l}\text { Emre Gül \& } \\
\text { Önder Yetişen }\end{array}$ & 2015 \\
\hline
\end{tabular}

In terms of the language, length and storyline this series, presented in Table 5, is the most simplistic of the examples in the study. It may be assumed that this series is aimed at children who are learning to read. The pictures are simplistic, devoid of detail with, for example, only the face of the child being depicted with at most two to three lines of writing on each page. Except for the use of their names, the stories provide no information about the famous people, what they did, who they were, etc.

Table 6. PAN Yayınları - Biyografik Öyküler Dizisi (PAN Publishing Biographical Stories) Series (+7 years) ${ }^{10}$

\begin{tabular}{|c|c|c|c|}
\hline Book & Subject & Author & Date \\
\hline $\begin{array}{l}\text { Tanburi Cemil Bey. Cemil'in Gizli } \\
\text { Konserleri } \\
\text { (Cemil's Secret Concerts) }\end{array}$ & $\begin{array}{l}\text { A story about Tamburi Cemil Bey, an Ottoman tambur, yaylı } \\
\text { tambur, kemençe, and lavta virtuoso and composer, who has } \\
\text { contributed to the taksim genre in Ottoman classical music. }\end{array}$ & $\begin{array}{l}\text { Serhan } \\
\text { Aytan }\end{array}$ & 2015 \\
\hline $\begin{array}{l}\text { Cemal Reşit Rey. Kuğu Kuşunun } \\
\text { Şarkısı } \\
\text { (The Swan's Song) }\end{array}$ & $\begin{array}{l}\text { The story of Cemal Reşit Rey's life. A Turkish composer, pianist, } \\
\text { script writer and conductor, well known for a string of successful } \\
\text { and popular Turkish-language operettas; one of the five } \\
\text { pioneers of classical music in Turkey known as 'The Turkish Five' } \\
\text { in the first half of the twentieth century. }\end{array}$ & $\begin{array}{l}\text { Aysel } \\
\text { Gürmen }\end{array}$ & 2015 \\
\hline $\begin{array}{l}\text { Aşık Veysel. Uzun Ince Bir Yol } \\
\text { (A Long \& Narrow Road) }\end{array}$ & $\begin{array}{l}\text { A story about how Âşı Veysel Şatıroğlu, discovered music. He was } \\
\text { a blind Turkish minstrel and highly regarded poet of folk } \\
\text { literature; a songwriter and a bağlama virtuoso, the prominent } \\
\text { representative of the Anatolian ashik tradition in the twentieth } \\
\text { century. }\end{array}$ & $\begin{array}{l}\text { Aysel } \\
\text { Gürmen }\end{array}$ & 2015 \\
\hline
\end{tabular}

The narrative style of the books, described in Table 6, is ideologically unmarked, with both illustrations and the text providing insight into the socio-cultural realities at the time in which the depicted figures lived. For example, in the volume about Tanburi Cemil Bey, in explaining that he used to escape to the cellar at his mother's house to practice his instruments, away from the eyes and ears of his family, an illustration of a typical food cellar common to rural areas in Turkey at the time depicted in the story is provided in detail. There are brass kitchen utensils, sacks in which grain and the like used to be stored, shelves on the walls for jars of homemade products, etc.

Whereas instilling a sense of cultural identity in children is important, adult writers construct this culturally embedded childhood when they write for children and children in turn construct childhood as they go along from fictions of various kinds and not merely from social experience (Williams 2014, 100-101). In the case of the series in question, the facts of the lives of the people are given in a fictional story format. This is common in many examples of such books in the West. Even when the characters of history are depicted, despite the fact that people of the same name actually lived they are actually 
representations and interpretations and in many ways little different from the characters of fiction (Cheetham 2013,158). The examples in this series are penned in line with this idea.

Table 7. Yapı Kredi Yayınları -Yapı Kredi James Meyhew Katie Series (3-8 years), and Turkish Painters' Series $(+10 \text { years })^{11}$

\begin{tabular}{|c|c|c|c|}
\hline Book & Subject & Author & Date \\
\hline $\begin{array}{l}\text { Katie and the Impressionists } \\
\text { (Katie ve İlenimci } \\
\text { Ressamlar) }\end{array}$ & $\begin{array}{l}\text { Katie gets to be a part of Monet, Renoir and Degas's } \\
\text { paintings as she walks through a museum. }\end{array}$ & $\begin{array}{l}\text { James Mayhew (Trans: } \\
\text { Dilek Erbaş Şeren) }\end{array}$ & 2015 \\
\hline $\begin{array}{l}\text { Katie and the Sunflowers } \\
\text { (Katie ve Ayçiçekleri) }\end{array}$ & $\begin{array}{l}\text { Katie gets to be a part of Van Gogh, Cezanne and Gaugin's } \\
\text { paintings as she walks through a museum. }\end{array}$ & $\begin{array}{l}\text { James Mayhew (Trans: } \\
\text { Dilek Erbaş Şeren) }\end{array}$ & 2015 \\
\hline $\begin{array}{l}\text { Katie and the Starry Night } \\
\text { (Katie ve Yıldızlı Gece) }\end{array}$ & $\begin{array}{l}\text { Katie gets to be a part of Van Gogh's paintings as she walks } \\
\text { through a museum. }\end{array}$ & $\begin{array}{l}\text { James Mayhew (Trans: } \\
\text { Dilek Erbaş Şeren) }\end{array}$ & 2015 \\
\hline $\begin{array}{l}\text { Kaplumbağalı Adam } \\
\text { Osman Hamdi Bey } \\
\text { (The Man with the } \\
\text { Tortoise Osman Hamdi) }\end{array}$ & $\begin{array}{l}\text { The life of Osman Hamdi Bey, an Ottoman administrator, } \\
\text { intellectual, art expert and also a prominent and } \\
\text { pioneering painter. He was also an accomplished } \\
\text { archaeologist, and is regarded as the pioneer of the } \\
\text { museum curator's profession in Turkey. }\end{array}$ & Dilek Maktal Canko & 2015 \\
\hline
\end{tabular}

The two series studied, given in Table 7, are dissimilar as in the translated Katie series, Katie lives an adventure with the works of famous painters and in the Turkish original the story of the life of a famous Turkish painter is depicted in a more traditional biographical narrative.

Table 8. 1001 Çiçek Kitapları - Büyük İnsanların Hikayeleri (The Stories of Great People) Series (+7 years), and Arkadaşım (My Friend) Series (+6 years) ${ }^{12}$

\begin{tabular}{|c|c|c|c|}
\hline Book & Subject & Author & Date \\
\hline $\begin{array}{l}\text { Leonardo's Palette } \\
\text { (Leonardo'nun Paleti) }\end{array}$ & $\begin{array}{l}\text { A biography of Da Vinci's life through the } \\
\text { adventures of Digby and Hester, two siblings who } \\
\text { discover objects at Mr Rummage's stand at the } \\
\text { flea market. }\end{array}$ & $\begin{array}{l}\text { Gerry Bailey \& Karen } \\
\text { Foster (Trans: Ömür } \\
\text { Özyurt) }\end{array}$ & 2013 \\
\hline $\begin{array}{l}\text { Mozart's Wig } \\
\text { (Mozart'ın Peruğu) }\end{array}$ & $\begin{array}{l}\text { A biography of Mozart's life through the } \\
\text { adventures of Digby and Hester. }\end{array}$ & $\begin{array}{l}\text { Gerry Bailey \& Karen } \\
\text { Foster (Trans: Ömür } \\
\text { Özyurt) }\end{array}$ & 2013 \\
\hline $\begin{array}{l}\text { Galileo's Telescope } \\
\text { (Galileo'nun Teleskobu) }\end{array}$ & $\begin{array}{l}\text { A biography of Galileo's life through the adventures } \\
\text { of Digby and Hester. }\end{array}$ & $\begin{array}{l}\text { Gerry Bailey \& Karen } \\
\text { Foster (Trans: Ömür } \\
\text { Özyurt) }\end{array}$ & 2013 \\
\hline $\begin{array}{l}\text { Els Amics Dels Pintors Van Gogh } \\
\text { (Van Gogh Arkadaşım Vincent) }\end{array}$ & $\begin{array}{l}\text { A child meets Van Gogh and sees his paintings, } \\
\text { studies them. }\end{array}$ & $\begin{array}{l}\text { Anna Obiols (Trans: } \\
\text { Berna Yilmazcan) }\end{array}$ & 2013 \\
\hline $\begin{array}{l}\text { Els Amics Dels Pintors Degas } \\
\text { (Degas Arkadaşım Edgar) }\end{array}$ & $\begin{array}{l}\text { A child meets Degas and he paints her while she } \\
\text { and her classmates are dancing (ballet). }\end{array}$ & $\begin{array}{l}\text { Anna Obiols (Trans: } \\
\text { Berna Yılmazcan) }\end{array}$ & 2013 \\
\hline $\begin{array}{l}\text { Els Amics Dels Pintors Gauguin } \\
\text { (Gauguin Arkadaşım Paul) }\end{array}$ & $\begin{array}{l}\text { A child meets Gauguin and he paints his family and } \\
\text { village as they go on with their daily lives. }\end{array}$ & $\begin{array}{l}\text { Anna Obiols (Trans: } \\
\text { Berna Yılmazcan) }\end{array}$ & 2013 \\
\hline $\begin{array}{l}\text { Els Amics Dels Pintors Monet } \\
\text { (Monet Arkadaşım Claude) }\end{array}$ & $\begin{array}{l}\text { A child meets Monet who helps him rescue his } \\
\text { paper boat and the child watches as Monet } \\
\text { paints. }\end{array}$ & $\begin{array}{l}\text { Anna Obiols (Trans: } \\
\text { Berna Yılmazcan) }\end{array}$ & 2013 \\
\hline
\end{tabular}

The principle difference between the two series presented in Table 8 is that, in the first there is biographical information about the people and in the second there is only information about the paintings and very little information about the painters. 
Table 9. Can Çocuk Biyografi - (Can Children's Books Biography) Series (7-10 years) ${ }^{13}$

\begin{tabular}{|c|c|c|c|}
\hline Book & Subject & Author & Date \\
\hline $\begin{array}{l}\text { Louis Braille: The Boy who Invented } \\
\text { Books for the Blind } \\
\text { (Louis Braille Görmezlerin Kitap } \\
\text { Okumasını Sağlayan Çocuk) }\end{array}$ & A biography of the life of Louis Braille. & $\begin{array}{l}\text { Margaret Davidson } \\
\text { (Trans: Tülin } \\
\text { Sadıkoğlu) }\end{array}$ & 2015 \\
\hline $\begin{array}{l}\text { Ara Güler İyi Fotoğrafçı Dikiş Makinesiyle } \\
\text { de Fotoğraf Çeker } \\
\text { (Ara Güler- A Good Photographer Can } \\
\text { Capture Good Moments Even with a } \\
\text { Sewing Machine) }\end{array}$ & $\begin{array}{l}\text { A biography of the life of Ara Güler, an } \\
\text { Armenian-Turkish photojournalist, nicknamed } \\
\text { 'the Eye of Istanbul'. He is considered one of } \\
\text { Turkey's few internationally known } \\
\text { photographers. }\end{array}$ & Muharrem Buhara & 2013 \\
\hline
\end{tabular}

The series, which is presented in Table 9, studied contains not only translations but also originals moulded in line with the narrative elements of the translations and this is an example of the fact that adaptations and translations of children's books contribute to modifying and consolidating the literary canon (Rodriguez 2015, 133).

\section{The corpus of the study: similarities and difference between the translation and originals}

In analysing the corpus of books studied, several similarities and differences stand out. In both the translations and the originals:

1. the language of the texts is kept concise and simple;

2. the characters and the fonts used are clear and legible;

3. there are coloured illustrations and attractive paratexts (covers, back covers, etc.).

Also, in analysing the narratives of the translated and original biographies, several themes seem to be common to both. The child reader is:

1. taken on an adventure;

2. kept amused and positive;

3. given the opportunity to emphasise with the famous person depicted;

4. provided with pertinent and correct information.

Though the use of illustrations and paratexts, the concision of the texts, the use of specific language aimed at a specific age group, and the correctness of the information imparted in the books are all of interest to scholars studying such works, not to digress, examples for these have not been provided. ${ }^{14}$ The themes and the narratives are of interest to the study.

\section{Common themes 1: adventures}

In the case of the translated examples studied:

- In the Katie Series, Katie is taken to a museum where she lives adventures with the figures depicted in the painting. 
- In The Stories of Great People Series the children go on an outing to the flea market and visualise adventures with famous people while looking at the objects belonging to them.

- In the My Friend Series the child characters meet up with the painters and accompany them as they paint, thus living adventures with them.

Similarly, in the Turkish originals the child characters are also taken on an adventure:

- In the PAN Publishing Biographical Stories Series the child reader is taken on an adventure of discovery of the talent by a recitation of how the famous people depicted discovered their passion for their art.

- In the Tefrika Publishing Children's Literature Series the child reader is told the story of a mishap, a negative experience (an adventure) endured by the famous person in question and how the person overcomes this (i.e. an adventure about learning to care for nature, not attributing undue importance to material things, learning to form friendships in the classroom).

- In the TIMAŞ Series, the child character has a magical key which in each story takes him to the past to live an adventurous day with the famous person depicted.

In the translations and originals studied, the theme of adventuring seems to be central to the story. In this sense, the Turkish originals have copied this aspect of the biographical children's book genre from the originals.

\section{Common themes 2: a positive attitude about life}

A positive attitude about life and humour also seems to be a narrative component that the originals and the translations share. In this case, in all the books studied, there is an emphasis on a positive attitude about life throughout the book and in some cases there are also instances of humour. For example:

- In the PAN Publishing Biographical Stories Series the child reader is made aware of the hardships of the artists in question (e.g. Ashik Veysel is blind, Cemil bey's father is dead and he comes from a poor family, Cemal Reşit Rey lives a life of exile due to internal turmoil in the country) but in the end their love for their art, family, etc. makes them persevere.

- In the TIMAŞ Series, in each case there is a conflict in the story at the exact moment the leading child character enters the life of the famous person in question (i.e. a war is being fought in the cases of Barbaros, Piri Reis, Fatih, Halide Edip, Ertuğrul Gazi, Kanuni, Nene Hatun), a discovery is being made (i.e. Hezarfen), there is a conflict between side characters in the story which the famous person resolves (i.e. Nasreddin, Itri, Mevlana, Hacı Bektaş Veli), there is a contest (i.e. Koca Yusuf) and so on. And the famous people in question come through this 'event' triumphant.

- In the Tefrika Publishing Children's Literature Series in each case the child character feels low about something, but this is resolved (e.g. the child character wants a watch, does not get it, but understands that material things are not important [Küçük Turgut Uyar ve 
Saati 2015], the child want's a dog and smuggles one into the house and ends up adopting it [Küçük Fazıl Hüznü Dağlarca ve Köpeği 2015], etc.)

In the translations, the positive outlook on life is mostly humorous as the child lives through an adventure which is fun, (e.g. Katie Series; My Friend Series); the child is told a funny story (e.g. The Stories of Great People Series).

In all the examples studied there is an attempt at humour in places and generally an accentuation of a positive and loving attitude towards life and new experiences. This approach to storytelling is common to both the translations and the originals but there are differences in the details of depiction; this will be studied under differences.

\section{Common themes 3: developing an empathy with the famous person}

In each of the cases studied the child reader is allowed to develop empathy with either the child character in the story living an adventure with the famous person (e.g. My Friend, TIMAŞ Series) or is living an adventure with an artefact or a work of art belonging to the famous person (e.g. Katie Series, The Stories of Great People Series) or the famous person is depicted as a child (e.g. Tefrika Publishing Children's Literature, PAN Publishing, Can Publishing Series) allowing the child reader to empathise.

\section{Differences between the translations and originals}

In studying the books written by different authors, of course, the creativity and the artistic choices of the authors have to be taken into account. The way an author chooses to tell a story is a personal choice. But, when similar thematic and narrative choices are made systematically by authors from different publishing houses producing works in the same genre, this could also be viewed as something beyond artistic choice and probably as the norms of the genre in the specific culture.

First of all, there is a difference in terms of which types of famous people foreign authors have written about and Turkish authors have chosen to write biographies about. There may be several explanations for this. Initially, of course, both the translated foreign authors and the Turkish authors are limited by the existence of famous people to write about. In the case of the West, especially when the subject is classical music or contemporary world renowned painters, inventers, Western authors have a plethora of examples to draw from. In choosing from among these examples to translate into Turkish, of course the publishing houses show a tendency to choose figures who are known worldwide, for example choosing a book about Mozart versus a book about a lesser known composer, or choosing a book about Thomas Edison versus a book about a lesser known inventor who may have also contributed greatly to technology and development. In the case of Turkey, the examples seem to be statesmen, philosophers, a few painters and musicians/composers, etc.

At this juncture it must also be noted that in the case of some publishing houses (e.g. TIMAŞ) the famous people depicted are from the Ottoman era, creating a historical link between the contemporary Turkish child and Ottoman ancestry. In the case of the other publishing houses (i.e. Can, PAN, YKY, Tefrika) the famous people depicted lived in the era of the Republic of Turkey. There is a politically marked choice in both cases: a 
wish to embrace Ottoman heritage or a wish to show the face of modern day Turkey and those who contributed to its Westernisation and development.

Secondly, there seems to be a concentration on the artistic works in the examples from Western authors, whereas in the Turkish examples the lives and philosophies of the people seem to be more central. This is also predictable in that the profiles (i.e. the fact that they are statesman, philosophers, travellers) of the Turkish people make it difficult to relate to a 6-10 year old children the exact nature of the 'work/product' the famous person contributed to society.

A third difference seems to be the emphasis given in the narratives to certain phenomena. Since the first two differences are due to the 'subjects' being depicted, it is the third difference that initially displays the difference between the narrative traditions of the translations and the originals

In the Turkish versions there seems to be several points of emphasis and traditions of storytelling that are non-existent or less highlighted in the translations. These may be summarised as follows: an emphasis on family; an emphasis on correct and desired societal values; and emphasis on heroism and overcoming character shortcomings. These may be pinpointed as the instances in which the genre in question is appropriated according to the societal and literary norms of the Turkish readers; and thus, this is of interest to the translation scholar.

\section{Difference 1: emphasis on family}

The emphasis on family in the Turkish originals is very interesting. In all the biographies the child characters have contact with their family and family background is depicted in detail. To cite a few examples: In Hezarfen Üçmak Özgürlüktür (2013) though the famous person in question has no wife or children, his mother's, sister's and niece's anxiety for him are explained; in Ara Güler lyi Fotoğrafçı Dikiş Makinesiyle de Fotoğraf Çeker (2013) the photographers family life and his parents are portrayed in detail; in the Tefrika Publishing Children's Literature Series all the books are about the child's interaction with their parents; in TIMAŞ Series all the stories start with the child asking his parents a question and end with the child's anxiety to return from the adventure home to his parents; in the PAN Publishing Biographical Stories Series the family life and details of how the child character feels about his family are provided. In all the examples studied it seems to be important for Turkish authors from different publishing houses to tell the story of different famous people in different narrative formats to include what the child's family is like. In all the cases studied, the family is depicted as devoted, loving, caring and very central in the child's life. There is not a single example where family does not enter into the story in the Turkish originals.

The definition of children's literature depends 'largely on society's prevailing notion of the child', (Gerber 2008, 141). The examples in Turkish seem to depict the child as inseparable from the family. In her article on the trajectory of children's literature in Turkey, Çelik (2014) underlines that Turks viewed children differently from Europeans of the time during the Ottoman era $(2014,199)$; they were doted on, but not viewed as individuals, they were brought up to respect power and status in life. In a survey taken in 2011 (Çelik 2014, 201) the rate of Turkish men and women who stated that children were individuals the families could count upon on in their old age was $77 \%$ (as opposed to, for example, $7-8 \%$ in the 
USA and Germany). Thus, not only in their youth, but also as they grow older, children are viewed as integrally tied to their families.

In his seminal book about literature and translations in Turkey for children, N. Neydim draws the trajectory of how Turkish culture's view of the child developed in each era. In his research into how predominantly Muslim societies view children he quotes from experts in the field in saying that predominantly Muslim societies view the transition from childhood to adulthood as occurring in stages versus at certain age levels; adults are seen as being responsible for the upbringing of the child who they should protect and guide $(2000,21)$.

In line with societal norms and local trends in Turkish children's literature, the continual injection of the family in the examples studied is thus not a surprise, and only reflects predominant norms within Turkish society.

\section{Difference 2: didactics, societal values and norms}

The emphasis on teaching children something through literature and books is very clear in the Turkish versions. The most striking example of this is seen in the TiMAŞ Series where, at the beginning of each book, there is a small list entitled 'bu kitabı okuyan' ('the child who reads this book will') and the following are examples from this series:

be able to understand the hardships endured during the establishment of the Republic of Turkey; be able to understand the sacrifices one makes for country; notice that success depends on the individuals fulfilment of his/her duties and responsibilities; comprehend that to achieve something one has to plan. (Nene Hatun'la Bir Gün, p. 3)

research the lives of those people who contributed to humanity; develop an understanding of ecological responsibility. (Itrı'yle Bir Gün, p. 3)

develop an awareness about being respectful towards their elders; comprehend the value of research; develop a need to research his/her own history; grasp the importance of health and societal solidarity. (Kanuni'yle Bir Gün, p. 3)

develop a desire to learn Turkish traditions and make these traditions live on, understand the importance of respecting the elderly. (Osman Gazi'yle Bir Gün, p. 3)

notice that one should not give unnecessary importance to appearances, grasp that one need not stray from the right path, develop an interest in people with whom they share a common culture. (Nasreddin Hoca'yla Bir Gün, p. 3)

notice the importance of solidarity and unity in the Muslim countries. (Ertuğrul Gazi'yle Bir Gün, p. 3)

develop in terms of keeping up their courage and morale in the face of danger and negative occurrences. (Halide Edip'le bir Gün, p. 3)

show determination and patience in striving to reach his/her goals, comprehend that it takes hardship and perseverance to get a job done. (Koca Yusuf'la Bir Gün, p. 3)

discover that a kind word and being nice will go a long way in solving problems as opposed to anger and violence. (Hacı Bektaşı Veli'yle Bir Gün, p. 3)

In the PAN Publishing Biographical Stories Series the child characters are very careful to abide by the rules set by their parents (i.e. not to disturb the household in the case of 
Tanburi Cemil Bey. Cemil'in Gizli Konserleri 2015); respect the advice of their elders (i.e. Cemal Reşit Rey. Kuğu Kuşunun Şarkısı 2015); respect disabilities (i.e. Aşık Veysel. Uzun Ince Bir Yol 2015); and other examples of such teachings are also clear. In Kaplumbağalı Adam Osman Hamdi Bey (2015) the child feels regret when he upsets his parents; in the Tefrika Publishing Children's Literature Series they learn from their childish mistakes, that is, the importance of sharing information (Küçük Tezer Özlü ve Gece-Gündüz 2015), the importance of caring for nature and living things (Küçük Edip Cansever ve Çiçeği 2015) and in all the examples there is a lesson the child learns from an experience. In the Turkish examples, the child character learns something and this is done in a very overt manner with didactic recitations such as although he did not have a watch, he was dizzy from turning and lay flat on his back staring at the sky and 'he was happy...' (Küçük Turgut Uyar ve Saati 2015, 12). But, it must also be underlined that, except for the TIMAŞ Series, in the rest of the examples studied the didacticism is not ideologically or politically marked.

In analysing major themes in contemporary Turkish literature Stone $(2010,236)$ concludes that 'a good many of the texts share [...] a concern with life in Turkey, and equally important the citizens place within Turkish society.' He also underlines that a balance is achieved between understanding the cultural modernisation themes and also portraying the experiences, traditions and 'Turkish way of life'. As the cases given as examples show, even books for the 6-10 year old range seem to revert to such themes about the Turkish way of life.

Turkish authors seem to be functioning with an aim to 'incorporate the norms of society onto the child' at a young age (Kurultay 2014b, 359). Furthermore, the prevailing norms in literature for children in Turkey still seem to be that the child should please people, education should instil a certain mould, and family values should be paramount (Sezer 2006, 68). Others like Şirin $(1996,31)$ even argue that teaching children what is correct, making them 'good and honest people' should be the endeavour of literature; and Turkish stories are forsaken for translations (Kuşoğlu 1996, 53). As can be noted from the examples provided, these main trends noted by experts seem to continue in this new genre appropriated into Turkish.

\section{Difference 3: overcoming difficulties and character shortcomings}

Another theme that seems to be stressed in the Turkish versions of biographies is the perseverance and will to overcome character shortcomings and difficulties. Whereas there are rare references to this or any similar theme in the translations (e.g. Virginia Woolf the Writer of the Invisible 2012), the Turkish versions almost all contain a character that has to overcome shortcomings and must persevere.

For example, in the PAN Series the child reader is made aware of the hardships of the artists in question (see examples from previous section, 'Common themes 2') but in the end their love for their art, family, etc. makes them persevere.

In the TIMAŞ Series, in each case there is a conflict in the story at the exact moment the leading child character enters the life of the famous person in question (see examples from section 'Common themes 2 '), and the famous people in question come through this 'event' triumphant.

In the Tefrika Series, in each case, an issue the child character feels low about is resolved in a positive way. In the Mikado Series, in each case, the hardships the 
famous person endured and the struggles $s / h e$ went through to get to the point $s / h e$ is at and achieve something is emphasised. For example, in Edison Kimdir? (2015), the fact that Edison did not give up, that he fought against the prejudice of those who did not understand his inventions and he kept on going when he failed, etc. is accentuated.

Turkish researchers have produced studies in which they underline the importance, as they see it, of teaching children about hardship, perseverance and the importance of hard work. For example Karatay $(2007,463)$ underlines that teaching a child to react positively in cases of hardship is an endeavour that must be accomplished through children's stories. Kaya and Güven (2012) have conducted an impressive study on the use of history and social studies courses in Turkish primary schools; the authors make numerous references to how in addition to themselves other experts and the even the Ministry of Education in Turkey recognises that social studies courses entailing subjects such as history, sociology and the like, in addition to teaching children about their cultural heritage are also designed to help the child overcome difficulties in life by presenting pertinent and good examples of behaviour from others. Since this seems to be the prevailing norm in Turkish primary schools, it is not an arbitrary choice that such a theme is incorporated into the genre studied.

\section{Which repertoires do the originals draw from?: Turkish children's literature and children's literature translated into Turkish}

In considering the translated books and the originals studied side by side, there may be two views about what happened when the biographical books genre was produced for 6-10 year olds in Turkey. Initially, it is clear that in the presentation of the books, be it the illustrations, covers, or even the language used, Turkish authors and publishing houses are producing examples similar to those produced in the West. Secondly, in terms of the intention of the books, the fact that these are books written to engage a young reader with the life and works of a famous person, the examples in Turkish also reflect the norms of the examples from the West. A third and very central concern is, with the sale and reception of the translations, the fact that Turkish authors and publishing houses considered producing such works about famous Turkish people. In these senses the translations in question and the ones before them did serve as examples which led to the production of such a literary genre in Turkish.

But, the translations did not serve as one-size-fits-all models that could be copied. The Turkish writers and publishing houses seem to have drawn from other repertoires besides that of the translations and also integrated features into the Turkish originals that set them apart from the translations. In other words, the appropriation of the genre is also grounded in the prevailing norms of literature for children in Turkey.

For centuries literature has had a leading role as the backbone of not only language teaching, but also as a tool for the instillation of morals, the raising awareness about culture and even the unification of a national community. This is especially true for children's books.

Unfortunately, some writers in Turkey have a misconception in that they believe that writing for children is an easy endeavour entailing simplification and the addition of pictures (Akal 2014, 342). Experts noted that the stories in Turkish entail idealised and unrealistic characters and examples of limited vocabulary (Batmankaya 2014, 344), even in the 
translated versions vocabulary levels do not seem to be gauged correctly in terms of age profiles (Erten 2014, 355). In short, it could be accepted that at this stage it is impossible to refer to a new style in Turkish children's literature and especially anything that can compete in terms of universal standards (Kurultay 2014a, 348).

\section{Conclusion}

In review of the findings, it may be stated that the genre itself was translated into Turkish in the sense that presently there are examples in Turkish. But, the translation of the genre, with the discourse strategies selected by the writers and probably advocated by the publishing houses, have become works about role models and correct behaviour advocated by society providing the child with two example repertoires to draw from: A foreign repertoire of books about famous people which are not written in a way as to inspire Turkish children, and Turkish examples which are didactic and serve as examples. So, one could question how far the current examples of the genre in Turkish really display that the authors and publishing houses have understood that biographies for children are basically works they can learn from and serve as inspirations for them to pursue their passions (in the arts, literature, music, philosophy, etc.).

Paker $(2004,6)$ refers to the soul and spirit of the Turks 'as a nation somehow divided or suspended between East and West.' The examples in the study support this claim in that there are examples of the genre using similar themes, messages, narrative styles and paratexts, but the local, more traditional norms injected into contemporary Turkish children's literature also seem to prevail. When Chavez Vaca $(2015,78)$ refers to 'adults with a hardline stance on morality' and 'good manners' and editors 'who prioritize profit, rather than artistic vision' in the case of Ecuadorian children's literature, he is not off the mark in reference to Turkish children's literature either.

In research into translated children's literature in Turkey the findings seem to point to the fact that, even though in this era it has become impossible to impose certain norms on the child, children's literature and choices in translated children's literature in Turkey still seem to aim to do so (Neydim 2003, 60). The financial crises and the political and social changes of the 1980s fuelled translations from the West, also giving publishing houses a different consumer profile that now placed the child at the centre of the family. This development led to the increase in publications for children from that era onwards (Neydim 2003, 64). The main consumer group that publishing houses aim to attract with their translations for children are not children but their parents (Neydim 2003, 72). In the case of the corpus studied, it may be assumed that the didacticism in the books is meant to attract the adult buyers, not the child readers. Thus, interestingly, each publisher still seems to insinuate an ideology in the books for children be it modernist, socialist or conservative (Neydim 2014, 350).

It may be surmised that the evolution and the choice of biographical children's literature is still at the mercy of dominant ideologies prevalent in Turkey. There seems to be a prevailing norm to write for children with a conservative ideology injected into the texts. Furthermore, there is an effort to try to integrate traditional Turkish storytelling moulds through the use of ideas imported through translation like the use of adventure stories, using the child's imagination and empathy skills and psychology. There seems to be a predominant nationalist and traditionalist trend in Turkish biographical children's literature; 
the didactic nature of the books written for children points to the fact that Turkish children's literature still does not have a large corpus of examples that would serve to replace the classics of the West and furthermore move away from the dominant ideology of the society.

In conclusion, the number of translations and originals lay evidence to the fact that there will be a growing interest in biographical children's literature which will hopefully enrich the variety and the content and quality of originals in Turkey. As the options available on the market today reflect, though there is some work underway writing biographies about famous people for 6-10 year olds in Turkish, in some cases the examples seems to be used to instil certain dominant ideologies in children and others are a work in progress towards better examples.

In short, in answer to the question what happened after the genre was incorporated into children's literature in Turkish, in some cases Turkish authors and publishing houses found a middle ground in which they incorporated Turkish storytelling techniques and shared with children their cultural and historical heritages, but in others, publishers also found a new way and means to serve Turkish children the traditional didactic societal norms of correctness with ideologically marked texts.

\section{Notes}

1. The most popular and largest bookstores in Ankara are situated in shopping malls. They are: Arkadaş Kitabevi, Dost Kitabevi, ADA Kitabevi, Remzi Kitabevi, D\&R Kitabevi. The largest stores where they have a variety of collections for children were chosen.

2. The age ranges the books appeal to are stated on the front or back covers of the books, or the web sites of the publishing houses.

3. It should be noted that there are also examples of books about science, arts and society where sections are devoted to famous people in the field. But, the books included in the corpus are specifically about famous people themselves, not about, for example, inventions in physics, etc.

4. Some of the series studied are written in Turkish, whereas others are translations and some are a mix of the two, with some books being translated and Turkish authors contributing to the series. In some cases, a few of the books in the series are taken as examples, in others the full series has been studied.

5. 22 books, 21 of which are about significant figures, political and military institutions in Ottoman history. For full range of series see official website: http://www.eglencelibilgi.com/ diziler/eglenceli-tarih.aspx?s=1

6. 16 books. The storyline is: a boy in primary school has to research historical figures and uses his magical key to go back in time and spend a day with that famous person. For full range of series see official website: http://www.timascocuk.com/kitaplar/unlulerle-bir-gun.aspx?s=1

7. Six books chronicling the lives of contemporary figures like the first woman pilot in Turkey, a famous TV comedian, and Ottoman architects and map makers. For full range of series see official website: http://www.mikadococuk.com/default.aspx?cid=12037\&cp=2

8. Two books. For details of books mentioned see: http://www.elmayayinevi.com/cocukkitaplari-kat4.html

9. Six books chronicling short childhood adventures of contemporary Turkish writers, poets. The web site for this publishing house is under construction: http://www.tefrikayayinlari.com/

10. Three books about famous Turkish musicians and composers, chronicling their lives and interest in music. For details of series see official website: http://pankitap.com/urun-kategori/pan/ cocuk-kitaplari/

11. This publishing house has two different series about painters: A translated series about foreign painters and a volume on a famous Turkish painter written in Turkish. For Katie Series see: 
http://kitap.ykykultur.com.tr/arama?search=Katie. For book about Osman Hamdi Bey see: http://kitap.ykykultur.com.tr/kitaplar/kaplumbagali-adam-osman-hamdi-bey

12. The first series is about the adventures of several children at a flea market where they learn about famous people through the objects that they find there. The second series is about famous painters and how children make friends with them. Official website cited in the books: www.binbircicekkitaplar.com

13. Six books, four of which are translations of biographies about Erich Kastner, Roald Dahl, Louis Braille, Marier Curie and two written in Turkish about Chopin and Ara Güler. For complete series see: http://www.cancocuk.com/firma_urun.asp?dzid=23529

14. Researchers interested in these aspects can find the copies and the pictures of the books on the Internet sites of the publishing houses mentioned in the study.

\section{Disclosure statement}

No potential conflict of interest was reported by the author.

\section{Notes on contributor}

Şirin Okyayuz is a trainer and researcher at Bilkent University Department of Translation and Interpreting in Ankara, Turkey. Her research fields are literary translation, audio-visual translation and translator training. She is also a translator of children books, bestselling novels in the popular genre, drama for the stage, and books on politics and philosophy.

\section{ORCID}

Şirin Okyayuz (D) http://orcid.org/0000-0001-7512-2764

\section{References}

Akal, Aytül. 2014. "Dünya Dillerine Açılan Kapı." Türk Dili Dil ve Edebiyat Dergisi. Çocuk ve Illk Gençlik Edebiyatı Özel Sayısı. Cilt CVII, Sayı 756. 342.

Ateş, Kemal. 1998. Gülten Dayığolu'nun Çocuk Romanları. Ankara: T.C Kültür Bakanlığı Türk Tarih Kurumu Basımevi.

Batmankaya, Murat. 2014. "Ebediyat Çok Azların İşidir." Türk Dili Dil ve Edebiyat Dergisi. Çocuk ve Illk Gençlik Edebiyatı Özel Sayısı. Cilt CVII, Sayı 756. 343-345.

Çelik, Tuğba. 2014. "Türkiye'de Çocuk Olmanın Tarihi: Doğan Kardeş Dergisi." In Kazım Taşkent, Yapı Kredi ve Kültür Sanat, edited by Hasan Ersel. İstanbul: Yapı Kredi Yayınları.

Chavez Vaca, Wladimir. 2015. "Return to Arcadia: Meidators, Marketing and Restrictions on Ecuadorain Children's Literature." New Review of Children's Literature and Librarianship 21 (1): 77-90. doi:10.1080/13614541.2015.976096.

Cheetham, Dominic. 2013. "History in Children's Historical Fiction: A Test Case with the Baker street Irregulars." New Review of Children's Literature and Librarianship 19 (2): 157-173. doi:10.1080/ 13614541.2013.813341.

Cotton, Penni. 2000. "European Children's Literature: Translating Words and Pictures." New Review of Children's Literature and Librarianship 6 (1): 67-75. doi:10.1080/136145400009510629.

Daldeniz, Elif. 2010. "Introduction: Translation, Modernity and its Dissidents: Turkey as a 'Republic Of Translation."' Translation Studies 3 (2): 129-131. doi:10.1080/14781701003647327.

De Groot, Jerome. 2010. The Historical Novel. London: Routledge.

Erten, Asalet. 2014. "Çeviri Çocuk Edebiyatının Temel Sorunları ve Çözüm Önerileri." Türk Dili Dil ve Edebiyat Dergisi. Çocuk ve Ilk Gençlik Edebiyatı Özel Sayısı. Cilt CVII, Sayı 756. 354-355.

Even-Zohar, Itamar. 1990. "The Position of Translated Literature within the Literary Polysystem." Poetics Today 11 (1): 45-51. 
Gerber, Leah. 2008. "Building Bridges, Building a Bibliography of Australian Children's Fiction in German Translation 1854-2007." New Review of Children's Literature and Librarianship 14 (2): 141-157. doi:10.1080/13614540902835186.

Haider, Syed Jalaluddin. 1998. "Children's Literature in Urdu." New Review of Children's Literature and Librarianship 4 (1): 107-118. doi:10.1080/13614549809510607.

Karatay, Halit. 2007. "Dil Edinimi Ve Değer Öğretimi Sürecinde Masalin Önemi ve İşlevi.” Türk Eğitim Bilimleri Dergisi 5 (3): 463-475.

Kaya, R., and A. Güven. 2012. "Illköğretim Yedinci Sinif Öğrencilerinin Sosyal Bilgiler Derslerinde Tarih Konularinin İşlenişi ve Tarihin Değeri Ille İlgili Görüşleri." Turkish Studies - International Periodical For The Languages, Literature and History of Turkish or Turkic 7 (2): 675-691. http://turkishstudies.net/ Makaleler/1493498133_44_kayaramazan_675-691.pdf.

Kurultay, Turgay. 1999. "Cumhuriyet Türkiyesi'nde çevirinin ağır yükü ve TÜrk hümanizması." Alman Dili ve Edebiyatı Dergisi 1998: 13-36.

Kurultay, Turgay. 2014a. "Çeviride Belirleyici Olan Alıcı Taraftır." Türk Dili Dil ve Edebiyat Dergisi. Çocuk ve İlk Gençlik Edebiyatı Özel Sayısı. Cilt CVII, Sayı 756. 348-349.

Kurultay, Turgay. 2014b. "Çeviri Edebiyat Ülke Edebiyatının Canlandırıı Bir Parçasıdır." Türk Dili Dil ve Edebiyat Dergisi. Çocuk ve IIlk Gençlik Edebiyatı Özel Sayısı. Cilt CVII, Sayı 756. 359-360.

Kuşoğlu, T. Taner. 1996. “Çocuk, Edebiyat ve Televizyon.” Türk Edebiyatı. Ekim 1996, Sayı: 276, Yıl:24. 53. Neydim, Necdet. 2000. Çocuk ve Edebiyat: Çocukluğun Kısa Tarihi, Edebiyatta Çocuk Figürleri. İstanbul: Bu Yayınevi.

Neydim, Necdet. 2003. 80 Sonrası Paradigma Değişimi Açısından Çeviri Çocuk Edebiyatı. İstanbul: Bu Yayınevi.

Neydim, Necdet. 2014. "Yerel Olamamak Evrensel Olamamanın Temel Nedenidir." Türk Dili Dil ve Edebiyat Dergisi. Çocuk ve İlk Gençlik Edebiyatı Özel Sayısı. Cilt CVII, Sayı 756. 350.

Özdeş, Müfit. 1999. "Geçmiş Zamanın Bilim Kurgu Çevirileri ve Çocuk." In Cumhuriyet Dönemi Edebiyat Çevirileri Seçkisi, edited by Öner Yağcı. Ankara: T.C Kültür Bakanlığı Gazi Üniversitesi İletişim Fakültesi Basımevi.

Öztürk, Serhat. 2002. Çivi çiviyi söker. Muazzez Imiye Çığ Kitabı. İstanbul: Türkiye İş bankası Kültür Yayınları.

Paker, Saliha. 2004. "Reading Turkish Novelists and Poets in English Translation: 2000-2004." Translation Review 68 (1): 6-14. doi:10.1080/07374836.2004.10523859.

Rodriguez, Beatriz. 2015. "Assessing Literary Adaptations and Translations for Children: Don Quixote in English." New Review of Children's Literature and Librarianship 21 (2): 133-160. doi:10.1080/ 13614541.2015.1078616.

Şenalp, Leman, and Ayten Şan. 1981. 1979 Dünya Çocuk Yılında Türkiye'de Yayımlanan Çocuk Kitapları Açıklamalı Kaynakçası. İstanbul: Onur Basımevi.

Sezer, Sennur. 2006. "Tezer Özlü Adlı Kız Çocuğu." Varlık, 74. Yıl, Sayı 1191, 1 Aralık 2006: 68-69.

Şirin, Mustafa Ruhi. 1989. Çocuk Edebiyatı Yıllığı 1989. İstanbul: Gökyüzü Yayınları.

Şirin, Mustafa Ruhi. 1996. “Çocuk Klasiklerini Okuma Kılavuzu.” Türk Edebiyatı, Haziran 1996, Sayı:272, YIl:24. 31-32.

Stone, Leonard. 2010. "Inside Turkish Literature: Concerns, References and Themes." Turkish Studies 11 (2): 235-250. doi:10.1080/14683849.2010.483864.

Susam-Saraeva, Şebnem. 2010. "Whose 'modernity' is it anyway? Translation in the web-based natural-birth movement in Turkey." Translation Studies 3 (2): 231-245. doi:10.1080/ 14781701003647483.

Teigland, Anne-Stefi. 1999. "Moderism in Children's Literature in Norway." New Review of Children's Literature and Librarianship 5 (1): 1-11. doi:10.1080/13614549909510611.

Toury, Geideon. 2002. "Translation as a Means of Planning and the Planning of Translation: A Theoretical Framework and Exemplary Case." Translations: (Re)shaping of Literature and Culture, edited by Saliha Paker, 148-165. İstanbul: Boğaziçi University Press.

Tuğcu, Nemika. 2004. Sırçe Köşkün Masalcısı. Kemalettin Tuğcu'nun Yaşamöyküsü. İstanbul: Can Yayınları. 
Williams, Sandra J. 2014. "Fireflies, Frogs and Geckoes: Animal Characters and Cultural Identity in Emergent Children's Literature." New Review of Children's Literature and Librarianship 20 (2): 100-111. doi:10.1080/13614541.2014.929437.

Yazıcl, Mine. 2007. “Repercussions of Globalisation on Verse Translation.” Perspectives 15 (4): 245-261. doi:10.1080/13670050802154036.

Yazıcl, Mine. 2010. "Turkish Versions of to the Lighthouse from the Perspective of Modernism." Perspectives 18 (1): 59-78. doi:10.1080/09076761003624027.

Yücel, Hasan Ali. 1946. "Yedinci Yıla Girerken." Tercüme Dergisi 7 (37), Ankara: Milli Eğitim Bakanlığı. 